\title{
A Comparative Analysis of Tense in the Standard Ígbò and the İmilikè Dialects
}

\author{
Juliana Chizọbam Eze \& Ifeoma M. Nweze \\ https://dx.doi.org/10.4314/ujah.v22i2.6
}

\begin{abstract}
This paper examines the syntactic and semantic analytic descriptions of tense in the standard Ígbò and İmilikè dialect with emphasis on both the affirmative and negative constructions. The study was inspired by the dearth of scholarly work in this aspect of the Igbo language (Niger Congo: Nigeria). The theoretical framework of Bull's (1963) analysis of Tense and Aspect is adopted. The analysis was justified with the use of concrete examples given from the standard Ígbò and the dialect. The findings reveal that in addition to the occurrence of tense in the standard Igbò and İmilikè dialect, there is also a morphological opposition between the present and past tense in both dialects. However, it was observed that there exist tonal distinctions which occur in the derivation of the different tense systems in both dialects in the affirmative and negative constructions. It also reveals that lexical units interact with tone and the components of INFIL (Inflection) to derive either the affirmative or the negative construction appropriately.
\end{abstract}

\section{Keywords: aspect, Ìmilikè dialect, inflection, morphological construction, standard Igbo, tense}

\section{Introduction}

It is necessary to state that some notable Ígbó scholars have in one way or the other, worked on the concept of tense in the Ígbò 
language, as they did their research on various topics of their choices. In their study they included some of the tenses and aspectual verb forms which we have in the language. This study is deemed necessary because our intention is to find out the similarities and distinctions between the Tense forms in standard Igbo and the İmilikè dialect. This was informed by a lot of intrigues revealed in the syntactic processes and tonal differences that came to play in the derivation of tense forms in İmilikè dialect of Ígbò, which have not been observed in the standard Ígbò by the works of Nweze (2009) on inflection and Eze's (2016) study of tense and aspect in İmilikè dialect, Consequently, we want to venture into a comparative study of the two dialects to satisfy our curiosity about some of the linguistic knowledge that hitherto has not been brought to limelight.

Some Ígbó linguists that worked on tense in the standard Ígbò previously are Nwanze (1991) who noted that we have three types of tenses in the language which include: the present tense, the past tense and the future tense; Ikegwụonu (2011) did the analysis of the present and the past tenses in Ígbò; Nweze (2009) while working on inflections in the İmilikè dialect included four types of tenses in the standard Ígbó and in the İmilikè dialect. These tenses are the progressive, the past, the future, and the unfulfilled tenses. Egwim (2008) proposed that we have three tenses in the Ígbó language: future tense, the past tense and the unfulfilled tense. Uwalaka (1997) asserts that there exist pluperfect tense in Igbo in addition to present and past tense.

Emenanjo (1987) discussed aspectual verb forms in the Ígbó language and argued that it is duration rather than absolute time reference that is emphasized in Ígbò. And if therefore, 
duration rather than explicit time is what is emphasized in Ígbò, then, aspect rather than tense is the appropriate category for referring to the Ígbó verbal system. He stated that the distinction between tense and aspect in the Ígbò is subtle and, in some structures, tense is not explicit. He observed that there are more cases of aspect than of tense alone or of tense-and-aspect combined, he therefore, lumped everything pertaining to tense and aspect in Ígbò under Aspectual verb forms. On the İmilikè dialect, the first study on tense and aspect was the study of inflections (see Nweze, 2009).

Genetically, the Igboid has been variously classified. The Ìmilikè dialect according to Achibong (2004) is under the Ǹsụ́kkā dialect clusters of the Northern Ígbò language. And it is further subclassified the Northern Group of Dialects by Nwaozuzu (2008:10) (see Table 1 below).

\section{Table 1: The dialects of Ígbó Language}

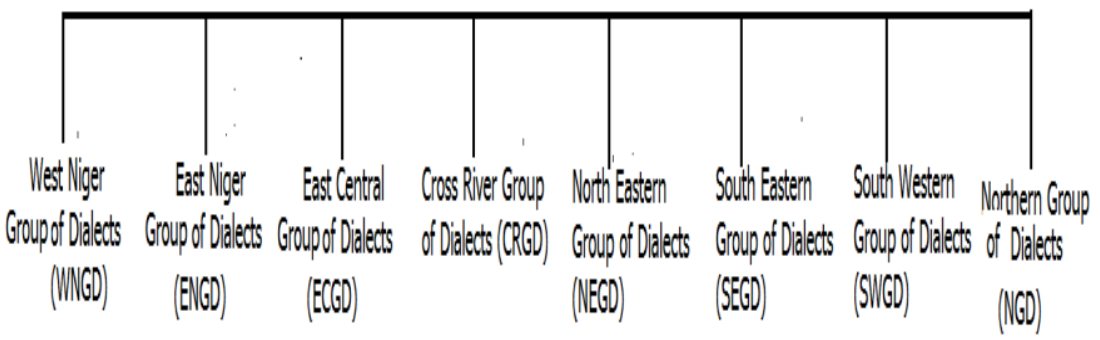

According to Oha (2004), the need for an in-depth dialectical study of language especially Igbo has been stressed by linguists on principally two grounds. First, that what is presently called the standard Ígbò is lexically and grammatically inadequate in handling the expressive needs of the Ígbó speakers and writers. 
Secondly, Ndịmele (1992) opines that to set the parameter of the whole language, it cannot be wholly grasped if individual dialects are not studied to discover their possible peculiarities and features with the main language. This situation therefore, prompts our study.

\section{Method of Data Collection}

Unstructured interview was used to elicit data from the informants from Imilike native speakers via random sampling technique while other respondents from the five main states which make up the Ígbòland were selected to ascertain the degree of differences and similarities which exist between the standard Ígbò and İmììkè dialect.

\section{Theoretical Framework}

The theoretical framework adopted in this work is based on Bull's (1963) analysis of Tense and Aspect as contained in Omamor (1982:99-105). The choice of the framework is due to its explanatory force in accounting for tense and aspect in the standard Ígbò and İmilikè dialect. This framework establishes that tense is a universal category, and this can be established in the Ígbò language generally, and in İmilìkè dialect, in particular. Bull's analysis of tense starts off from the position that "there are only three possible order relationship between events and any axis of orientation: the event being perceived may be anterior to, or simultaneous with, or posterior to the event used as axis of orientation (Omamor 1982: 99). Since, there are only three possible order relationships between an event and an axis of orientation, all order morphemes are in some sense synonymous with anteriority, simultaneity and 
posteriority. In consideration that every event takes place in time, it implies that every event has length and three aspects (perspective) that is, a beginning, middle, and an end. The absolute beginning and the absolute end are perceptible, but they do not have duration. Even though, the termination of an event is usually simultaneous with its perception, it is treated as anterior to the act of speaking, and it is the point of initiation of speech which serves as the axis of orientation of the point present that is "now" of utterance as Lyons (1968) refers to it. Bull's diagram obviously exhibits all the possible order relationships which the aspect (perspectives) of events, points and time intervals may have to an axis of orientation. An arrow represents either a time interval of the three aspects (perspectives) of an event, that is, the beginning, the middle or end of the event 


\section{Figure 1:}

\section{Order Relationships of Aspects, Points and Time Intervals to} an Axis

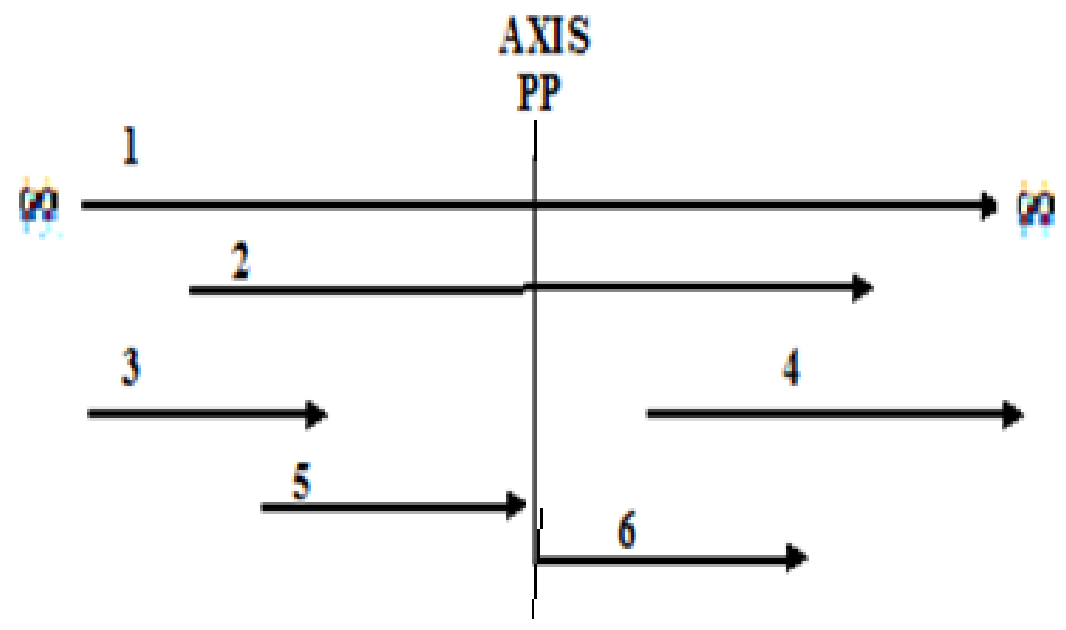

Omamor (1982:100) as cited in Bull (1963)

The numbers on the diagram above are interpreted as follows: ' 1 ' the speaker at "Axis" what is regarded as the "now" of utterance of Lyons (1968:305) can look backward or forward towards infinity. ' 2 ' The beginning of the action is anterior to PP, i.e. the time of speaking with which its middle is simultaneous. Its end is posterior to PP. In other words, an event began in the past and split into the future. ' 3 ' All the three aspects of this event are anterior to PP, i.e. the beginning, the middle and the end took place before the time of utterance. '4' All the three aspects of this event the beginning, the 
middle and the end are posterior to PP, i.e. the three aspects will still take place in the future after the moment of utterance. ' 5 ' The end of this event is simultaneous with PP. Its beginning and its middle must therefore be anterior to PP. ' 6 ' the beginning of this event is simultaneous with PP, its middle and its end must be posterior to PP. This implies that the events are still in progress at the PP.

In consideration of the order of relationships displayed on the diagram, Bull established several points of orientation:

(i) PP - the initiation of speech which serves as the axis of orientation the point present of a tense system

(ii) RP - this represents a point, which must have served as the point of initiation of speech at some time prior to the actual initiation of speech. For instance, when an individual says, "I saw the book", what he is actually doing is re-collecting that at some moment prior to the present moment, the seeing took place. Bull labels this past moment Retrospective Point (RP)

(iii) $\mathrm{AP}$ - This is anticipated point in time posterior to the moment of initiation of speech. It indicates a future point in time when it is anticipated that an event will take place. (Omamor 1982: 101).

In considering Bull's reference points, the re-collection and anticipation of events usually take place with PP. Recall and anticipation must take place with PP such that the contents of recollection and anticipation can be anterior to, or posterior to PP. The point of reference is illustrated with the diagram below.

\section{Figure 2:}

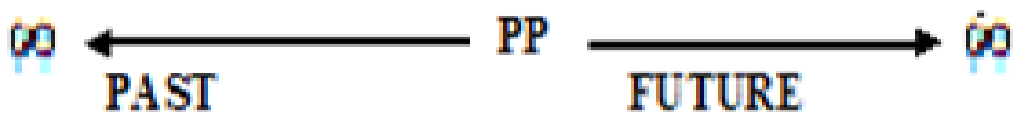


Omamor (1982:101) as cited in Bull (1963)

The person who is at PP in (figure 2 above) perceives a man can say, "I kill something". Nevertheless, a new initiation of speech, i.e. a new PP, he can then recall this perception along with the point in time of perception and say, "I killed something". This means that the original PP is obviously retrospective, it has changed to RP in the following diagram:

Figure3:(a)

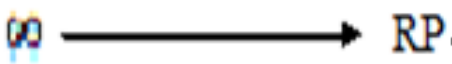

PP
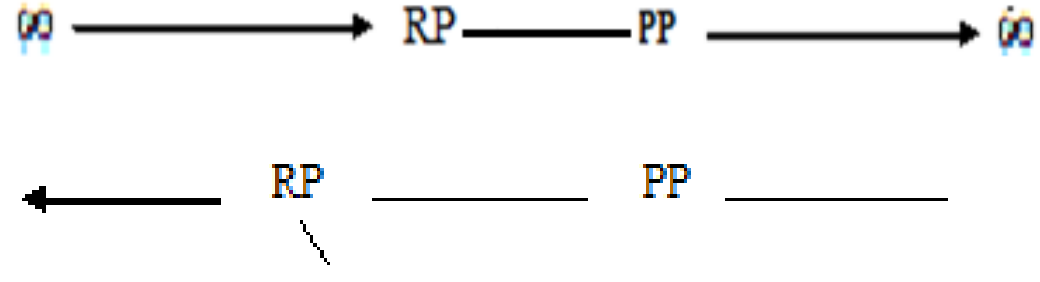

Time of Perception

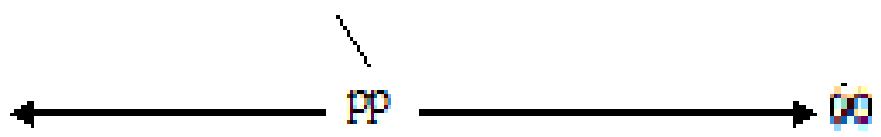

(b)

(Time of re-collection)I killed something Omamor (1982:102) as cited in Bull (1963)

In (figure 3b), when an individual says at his initiation of speech (a new PP), "I killed a man", it then means that he is re-collecting the event of "killing", that has taken place before the moment of speech 
does not really have an end; one can recall as many events as possible at PP, which the diagram below shows:

\section{Figure 4:}

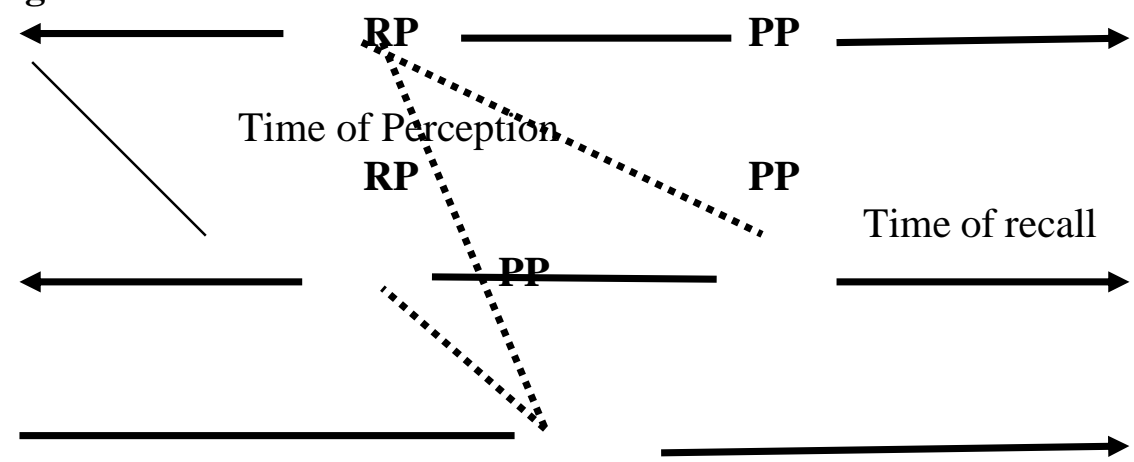

Omamor (1982:102) as cited in Bull (1963)

In the analysis of the sentential constructions which we are going to offer as instances, we will illustrate how all these are being applied in the standard Ígbò and the İmilikè dialect, at least, as it concerns the tense forms in both dialects.

\section{The concept of tense}

Táíwò and Angisto (2013) group the languages of the world based on how they mark their tenses. They affirm that the grammaticalization of time has been a feature of many languages of the world; as such it is an element of the universal grammar (UG). However, how this is marked abound in languages. In accordance with their viewpoint, the following are groups into which languages are classified based on how the languages mark their tenses. 
Group One: Languages that mark tense via the use of free morphemes as tense markers.

Group Two: Languages that make use of inflection (the use of affixes) to mark tense

Group Three: Languages that make use of both free morphemes and inflection to mark tense e.g. Tiv and English languages

Group Four: Languages that make use of null markers

Group Five: Languages that make use of null markers and may use either both free morpheme and inflection

We observe that the Ígbó language belong to the group which mark their tense using free morphemes and inflection just as is the case with the English and Tiv languages. Since in a construction, tense is responsible for determining whether an action or event is happening now, happened before, or will happen in the future time, Íkégwụ́ọ̣ṇ (2011) explains why Katamba (1983) adopts a three-point reference in relation to a particular moment. That moment is typically the moment of speaking or writing e.g. it indicates whether the event happened prior to the moment of speaking (past tense), is contemporaneous with the time of speaking (present tense) or subsequent to it (future tense). Katamba subsequently notes that in the morphology of many languages, three tense distinctions are obtained, though lacking in some others where two basic distinctions may be drawn between the past and non-past standing for both present and future.

Eyisi (2006) asserts that in line with the modern descriptions of English, three tense forms are used to express the notion of time. They are the present tense which is used to indicate an action going on at the time of speaking or a state that is existing; that is, it indicates the time NOW. The past tense, is used to refer 
to an action or state that has taken place before the present time; that is, time BEFORE NOW. The future tense refers to an action or state that will take place at some time in the future; that is TIME AFTER NOW. In this regard, I am, is in the present tense; I was, is in the past; and $I$ will be, is in the future tense.

Bull (1963)'s notion of tense is based on meaning rather than form. His observation is that at any given point in time, a model can imaginatively look either backward or forward towards infinity. The implication of this is that a model can perceive, recall or anticipate any event as seen in the following strings in English: I see/am seeing someone(re-collection) and I will see (anticipation). Based on the above construction, Bull establishes the following reference points: see Figure 4 above. For instance, when a model says, "I have seen the man", what he is actually doing is recollecting that at some point in time prior to the moment of utterance; the event of seeing took place. Bull's whole idea is that there are basically the present, the past and the future, Omamor (1982:101).

In accordance with Bull's perception, both the standard Ígbò and İmilìè dialect of Ígbò possess the three types of tenses: The present, the past and the future. It was observed that both dialects mark tense inflectionally by employing affixes and designated tense markers. There is also morphological opposition between the past, the present, and the future tenses in the Ígbó language and also in İmilikè dialect, which is in line with Bull's idea.

The present tense refers to the present time. In the standard Ígbò as well as in the İmilikè dialect, this type of verb form expresses the present or existential meaning. The events or state of affairs that are on-going presently at the time of speech. Ừwàlákà 
(1997) expresses that only a sub-set of Ígbó verbs occur in the present tense. She explains further that such verbs occur without

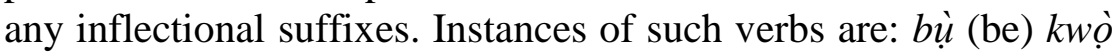
(carry + human) chì (carry) bù (carry) mà (tie), tù (tuck) and so on. These types of verbs are (CV) structured with only one syllable. They are consistently on low tones. (Ọfọ́màtá, 2005) is of the viewpoint that compound verbs can as well occur in the present tense; meaning that some verbs which possess more than one CV structure can be used to realize a present time meaning in Ígbó language. Such verbs are ábịá (come), ègó (buy) ázà (sweep) and so on.

We will first and foremost, discuss the set of verbs which cannot occur in a compound form, before we discuss those with more than one CV syllable.

\section{1 (a) The present tense in affirmative constructions in standard Ígbò}

In the derivation of the affirmative construction, the one syllable verb, that is, the verb involved in the construction stands alone while its complement follows suit. As have been specified, the lone syllable verb describes the action, event, or state of affairs that is being depicted in the utterance.

1.(a) Nwáànyị áhù nyà àkpà n' ákụ̣kụ

Woman/girl DET. pres-carry bag PREP. shoulder

"That woman is carrying her bag on her shoulder".

$\begin{array}{llll}\text { (b) Ó } & \text { kpù } & \text { ókpú } & \text { ọ́chá } \\ \text { S/he/it } & \text { pres-wear } & \text { cap } & \text { white }\end{array}$ 
"He is wearing a white cap" Or "He is putting on a white cap".

(c) Nwókốē áhụ̀ gbà ọ̀tọ́ Man/boy DET. pres-be naked "That man is naked".

These verbs nyà (hold), kpù (wear/put on), and $g b a$ (be) used in the constructions $1(\mathrm{a}-\mathrm{c})$ translate into the present time; that is, the present tense. The implication is that, the actions or events being portrayed in the sentences are occurring simultaneously at the moment of utterance.

In the derivation of the affirmative construction, the verb root (stem) stands, while, either a prefix or a suffix as the case may be, can be affixed to it. Nevertheless, depending on the NP subject, both prefix and suffix can be affixed to the verb root (stem). By implication, when the NP(s) subject is a noun, a noun phrase, or a plural pronoun, the verb concerned must possess a prefix. Some of the verbs may possess a suffix, but not all verbs. However, when the NP subject is a singular pronoun, the prefix is deleted, while verbs that possess a suffix retain them.

(e) Ọ́ bịá.

S/he/it pres-come

"Here, he comes".

(f) Ḿmáchúkwú é tù ó yá áhà

Ḿmáchúkwú prev. prefix pres-praise suffix him/her name "Mmachukwu praises her" Or "Mmachukwu is praising her". 
The two verbs bịá (come) and étùo (praise) used in the two sentences 1(e) and (f) above also translate into the present time; that is, the present tense.

This implies that the actions or events being described in the constructions is in the present time, occurring simultaneously at the moment of utterance.

\section{1 (b) The present tense in affirmative constructions in İmìlìè dialect}

The researchers discovered that what is obtainable in the standard Ígbò in this type of tense is equally what is obtainable in the İmilikè dialect. The verbs which occur in this type of tense according to Ùwàlákà (1997) have no affixes as each one possesses only one CV structure. This can rightly be observed here in the constructions which were given as instances.

The derivation is of the affirmative constructions are also the same as is the case in the standard Ígbò, since the lone CV structured verb stands alone in the construction, to describe the situation or event that is being specified in the utterance. In İmilikè dialect, the verbs are also consistently on low tones.

2. (a) Úchèńnà pà mónyi\# n' ọ́bà Úchènnà pres-carry water PREP. cup "Úchéńnà is carrying some water in a cup".

(b) Ọ́ kpạ̀ éwú jékónó n’ ime ìrwùrwè S/he/it pres-drag goat go-continuously PREP.inside grass/bush

"He is dragging a goat into the bush" 
All these one-syllable verbs which are: $p \grave{a}$ (carry) and $k p \grave{~(d r a g) ~}$ found in sentences $2(\mathrm{a}-\mathrm{c})$ translate into the present tense in the constructions in which they were employed. The actions, events or the states of affairs being described in those sentences are occurring concomitantly or concurrently with the moment of speech. Òfộmàtá (2005)'s standpoint about those set of verbs with more than one syllable which occur in the present tense in the standard dialect (Standard Ígbò) can as well be employed in the İmìlikè dialect.

In the derivation of the affirmative construction, the verb root (stem) stands, while, either the prefix or suffix, or both as the case may be, can be affixed to it. However, this depends on the $\mathrm{NP}(\mathrm{s})$ subject that is being employed in the construction. Consider these instances:

(c) Ànyí á bịa

We/us prev. prefix pres-come

"Here, we come/ "Here, we are".

(d) Ó chì é ye íhé

S/he/it pres-beat suffix him/her/it (some)thing "Here, he beats him" Or "He is beating him".

As is applicable in the standard Ígbò, the four verbs used in the sentences 2(c-d) ábịa (come), and chié (beat) translate into the present tense. By implication, this is due to the fact that the states of affairs or events being described in the constructions, is in the present time, occurring concurrently with the moment of the utterance. Employing Bull's (1963) theoretical framework in the 
analysis, this implies that the beginning of these events is simultaneous with the (PP) point Present, their middle and their end must be posterior to PP. By implication, it means that each event or action being described is still in progress at PP. The end point is that the situations being discussed in the sentences are not taking place after the time of utterance; but, rather, each is simultaneously occurring at the moment of speech.

\section{1 (c) The present tense in negative constructions in standard Ígbò}

In the standard Ígbò, all the constructions showing the negative formation in this type of tense are derived from their affirmative counterparts by the suffixation of the negative marker-ghil/ denoting "not" to the verb root (stem). However, in accordance with the vowel harmony which is very prevalent in the language, the negative marker ' $g h i$ ' (not) can as well be realized as - $g h i$ (not) that is, without diacritics in some environments.

The negative constructions are derived from their affirmative counterparts using this formula: verb root (stem) + -ghị/ghí according to the vowel harmony, as in the following negative constructions:

3. (ai) Òròmá ńdị áhụ̀ dị n’ ímé éféré Orange pl. DET. pres-be PREP. inside plate "Those oranges are inside the plate".

(aii) Òròmá ńdị áhụ̀ á dị ghị n’ ímé éféré Orange pl. DET. prev. prefix pres-be + NEG. PREP. inside plate

"Those oranges are not inside the plate". 
(bi) Í
gbà
áká
You ( $2^{\text {nd }}$ pers. sg. pro.) pres-hold-noyhing hand
"You (sg.) are not holding anything in your hand"/Or"You

(sg.) are empty handed".

(bii) Í

gbá ghì áká

You ( $2^{\text {nd }}$ pers. sg. pro.) pres-hold-nothing + NEG. hand "You (sg.) are not empty handed".

Here, the more than one CV structure verb types can be employed in the negative constructions by the suffixation of the negative morpheme: ghi'ghí meaning "not", to the verb root (stem) thus: verb root (stem) + ghịighị. See examples below:

(ci) Ànyí è gbù ó We/us prev. prefix pres-kill suffix him/her/it "We kill it".

(cii) Ànyí é gbu ghí ya We/us prev.prefix pres-kill + NEG. him/her/it "We do not kill it".

(di) Há à bịá They/them prev. prefix pres-come "Here, they come".
(dii) Há
á
bịá
ghị 
They/them prev. prefix come + NEG.

"They do not come".

\section{1 (d) The present tense in negative constructions in İmilìkè dialect}

In the İmilikè dialect, the negative constructions are derived by the suffixation of the negative morpheme/marker ga, which connotes "not" to the verb root (stem). It has to be stated that this does not take into cognizance the vowel in the verb root (stem) that is being employed in the construction. This means that despite the vowel in the verb root (stem) of any of the verbs employed in the construction, the vowel in the negative morpheme ga "not" would still remain the schwa (ə).

However, the schwa [ə] is realized in two forms in Ìmilikè dialect depending on the environment in which it occurs. For instance, the schwa [ə] is a central vowel. Nweéyà, (2010) comments that we have central vowels I and II in the dialect; and that they are represented thus: [ə] and [ə̣] respectively. The central vowel II /ọ / is pharyngealized in the dialect, while the central vowel $\mathrm{I} / \mathrm{\partial} /$ is not pharyngealized.

The vowel harmony which exists in the dialect stipulates that, whenever the vowel of the verb root (stem) being employed in the construction it must come from the group A ( $a, i, 0, u)$ vowels, the negative marker would be realized as $g$ ? "not". On the other hand, for the group B (e, i, o, u) vowels the negative marker would be realized as ga "not".. The formula used in the derivation is: verb root (stem) + gə/gạ. This negative morpheme - gá/gạ "not" is a counterpart of the negative suffix -ghí-ghị signifying "not" in the standard Ígbò. 
Let us consider the following constructions:

4. (ai) Ànyí nọ̀ nwàmbé ha We/us pres-be here DET. "We are here".

(aii) Ànyí á nọ̀ gạ nwàmbé ha We/us prev. prefix pres-be + NEG. here DET . "We are not here".

(bi)
Ó
kpà
yà
n’ ệà̀

S/he/it pres-hold-tightly him/her/it PREP. armpit "She is holding it tightly under her armpit".

(bii)
Ó
kpà
gạ
yà
n' évọ̀

S/he/it pres-hold-tightly + NEG. his/hers/its PREP. armpit

"She is not holding it tightly under her armpit".

In the Ìmilìkè dialect, the employment of the other types of Ígbó verbs with more than one syllable which can occur in the present tense can take this format. In the derivation of the negative construction, the negative marker or suffix -ga/gà meaning "not", is suffixed to the verb root (stem). Let us consider these sentences

(ci) Ó ryì é ńryí ộmọ

S/he/it pres-eat suffix food DET.

"Here, She eats the food

(cii) Ó ryi gá ńryí ộmọ 
S/he/it eat + NEG. food DET. "She does not eat the food".

Constructions $3(\mathrm{a}-\mathrm{d})$ in the standard Ígbò, and $4(\mathrm{a}-\mathrm{c})$ in the İmilikè dialect are in pairs, (i and ii). In 3 (ai - di) in the standard Ígbò, as well as 4 (ai -ci) in the İmilìkè dialect, we have the affirmative constructions, whereas, the sentences in 3 (aii - dii) in the standard Ígbò, and also in 4 (aii - cii) in the İmìlikè dialect, we have their negative counterparts.

This implies that the beginning of the events is simultaneous with the (PP) Point Present, its middle and its end must be posterior to the PP. The implication of this is that the situations/events being described in the sentences in 3(ai - gi) in the standard Ígbò, as well as those in 4(ai - fi) in the İmilikè dialect are still in progress at PP.

However, the negative sentences in 3(aii - dii) in the standard Ígbò, as well as those in 4(aii - cii) in the İmìlikè dialect describe actions, events or states of affairs that are anterior to the time of utterance. The sentences in 3(ai - di) in the standard Ígbò, as well as those in 4(ai - ci) in the İmilikè dialect are situations or events which, at the moment of utterance, have not taken place, but may however, take place later in the future.

\section{1(e) Observations and summary on the present tense the affirmative and negative constructions in the standard Ígbò and Ìmilikè dialect}

In both the affirmative and negative constructions, the NP(s) subject retains its inherent/lexical tones. The first set of the Ígbó verbs with one syllable $(\mathrm{CV})$ structure have all low tones in the affirmative constructions. However, in the negative constructions, 
each has a high tone preverbal prefix $a-/ e$ - when the NP(s) is a noun, a noun phrase, or a plural pronoun, Nevertheless, in the second set of the Ígbó verbs which have more than one (CV) syllable, when the $\mathrm{NP}(\mathrm{s})$ is a noun, a noun phrase, or a plural pronoun, the verb has a low tone harmonizing verbal prefix which may be $a-/-e$, in the affirmative. Besides, some of the verbs may possess a suffix in the affirmative construction regardless of the type of NP(s) subject in place. In negative constructions, the suffix gets deleted. It is worthy of note that in negative constructions, the prefix always possesses a high tone in both the standard Ígbò and Imilikè dialect. Besides, in the second set of verbs which has more than one $\mathrm{CV}$ structure, when the NP is a singular pronoun, there is no preverbal prefix in both the affirmative and negative constructions in both dialects.

In the negative construction in both the standard Ígbò and İmilikè dialect, in both sets of verbs; that is the verbs that have only one syllable structure and those that possess more than one syllable structure, the preverbal prefix can sometimes be on a high tone while the tone on the vowel of the verb root (stem) is a downstep, then, that on the negative suffix is a high tone. However, depending on the tone class of the verb, the vowel on the verb root (stem) can also be on a low tone in negative construction, even when the tone on the prefix is a high tone. When the tone on the vowel of the verb root (stem) is a low tone, then, that on the negative marker will likewise, be on a low tone.

On the other hand, when the NP subject is a singular pronoun, the pronoun possesses a high tone, while the vowel of the verb root (stem) has a downstep in negative constructions, then the tone on the negative suffix is a high tone. Sometimes, however, the tone on the vowel on the verb root (stem) can also be on a low tone 
in negative construction, even when the tone on the NP singular pronoun is a high tone. This nonetheless, depends on the tone class of the verb. When the tone on the vowel of the verb root (stem) is a low tone, that on the negative suffix will likewise, be on a low tone. When the NP subject is a singular pronoun, the pronoun, the preverbal prefix gets deleted.

\section{2 (a) The past tense in the affirmative constructions in standard Ígbò}

In the standard Ígbò, the past tense formation is derived by the suffixation of the -rvpast marker or morpheme to the existing verb root (stem). The derivation is carried out using this formula: verb root $($ stem $)+-r v$ past morpheme. It is also observable that in the standard Ígbò, the $-r v$ past tense marker rhymes with the verb root (stem). This is because the vowel of the $-r v$ past tense marker must be the same as the vowel in the verb root (stem).

9. (a) Ńnà há

kọ

rọ ji ǹkè úkwú afọ a Father they/their cultivate + -rv (PAST) yam of/that of great/big this year

"Their father cultivated a lot of yams in his farm this year

(b) Chúkwú mè rè ì íhé úkwú m̀gbé áhụ God do + -rv(PAST) I/me (some)thing great/big time DET. "God did a great thing for at that time". 


\section{2 (b) The past tense in the affirmative constructions in İmilikè dialect}

In İmilikè dialect, it was discovered just as in the standard Ígbò, the past tense formation refers to a type of class maintaining affixes; that is, inflectional suffixes that discuss events in the past (Nweze 2009). These suffixes combine with the verb root (stem) to express past dynamic meanings. In the dialect, the derivation of past tense formation is arrived at using this formula: the verb root (stem) + $r v$ past morpheme. Unlike the standard Ígbò, the vowel of the $-r v$ past in İmilikè dialect does not rhyme with the vowel in the verb root (stem); that is the vowel of the first (CV) syllable in the construction. This is because, in İmilikè dialect, the vowel in the $r v$ past tense morpheme is always the schwa (ə) which is always silent. And, despite whichever verb is concerned in the dialect, the vowel in the - $r v$ past tense morpheme is always uniformly realized as a schwa (ə) in the dialect. The formula for the past tense derivation is this: verb (stem) + -rv past tense marker, where the $v$, in the $-r v$ past is always either the central vowel (ə) or (o). See instances below:

10. (a) Gọ̀ziéchúkwú là rọ̀ ụulọ̀ áhwụa ộmọ Gọ̀ziéchúkwú go + rv (PAST) home year DET. "Gọ̀ziéchúkwú went home that year".

(b) Ńdạ́ úwé ójî̀ jì rà nodạ óshi n' Pl. (people) cloth cloth catch/hold + -rv (PAST) pl. (people) thief PREP. áshụiwá ụnyáà market yesterday "The police caught thieves in the market yesterday". 
A clear observation of the constructions in $9(a-b)$ in the standard Ígbò, as well as the ones in $10(\mathrm{a}-\mathrm{c})$ in the İmilikè dialect will reveal that they are describing situations, events or states of affairs that are definitely anterior to the time of the utterance. This implies that the beginning, middle and the end of the events or the states of affairs being described took place before the time of the moment of speech. In analyzing the sentences, we will observe that the sentences in 9 (b) in the standard Ígbò as well as those in 10 (c) in the İmilikè dialect describe events or situations that are prior to the time of speech, without reference to when exactly the events or the actions took place. Ígbò, in sentences 9 (a) the adverb of time 'afo $a$ ' which means "this year" is used to indicate the exact time in which the events or the situations took place. In the same vein, in 9(b) the determiner phrase ìgbè áhù which implies "that time" is equally employed to ascertain the exact time the event being described took place.

On other hand, in the İmilikè dialect, the adverbial phrase of time in the sentence10(a) áhụ̂á ọmọ which implies "that year", and an adverb of time in sentence 10 (b) áshụánwá nwa which denotes "two days ago" are all employed to indicate succinctly or concisely the exact time that the actions, events or situations being described in the sentences took place. In other words, with or without an "unanchored" time adverb, determiner phrase, or prepositional phrase of time, in the İmilikè dialect, the constructions still clearly possess a past tense interpretation.

\section{2 (c) Past tense in negative constructions the standard Ígbò}

It is noteworthy to state that all the negative constructions showing past tense forms in the standard Ígbò are derived by suffixing the 
negative marker - ghi/-ghi denoting "not", to the verb root (stem) in accordance with the vowel harmony which is prevalent in the language. Obviously, some Ígbó linguistic scholars like Nwézè (2009), Òfọ́màtá (2005) etc. have already signified that in the derivation of a negative construction from its affirmative counterpart in the standard Ígbò, the negative suffix to be applied is -ghi/-ghí. It is the same with the present tense which has been mentioned. It is however discovered by the researchers that, in the derivation of past tense in a negative construction, some verbs take the clitic ri/ri, besides the negative suffix $g h i / g h i$ when the negative construction is being realized. Some of the Ígbó verbs that need to take on the clitic ri/ri besides the negative marker ghi/ghi in some

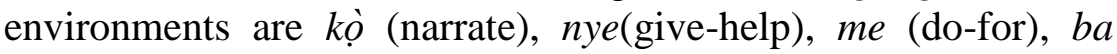
(scold). Without suffixing the clitic ri/ri to the negative suffix, either of these two things may happen: non realization the real intended meaning or the construction would be ungrammatical. The formula for the derivation of the negative construction from its affirmative counterpart is: verb (stem) + ghi/-ghí, + (ri/ri ) according to vowel harmony, as shown in following constructions: 11. (ai) Ọ́ tụ̀ rụ̀ bọọ̣lụ

$\mathrm{S} /$ he/it throw + rv (PAST) ball "She threw the ball".

(aii) Ọ́ tụ ghị bọọ̣lụ

S/he/it throw + NEG. ball "She did not throw the ball". 
(bi) Ứkọ̀chúkwú nye re nwáànỵ̣ ísí-ḿkpe áhụ áká Priest/pastor/Reverend give + -rv (PAST) woman/girl widow DET. hand "The pastor helped that widow".

(bii) Ụ́kọ̀chúkwú é nye ghí rí Priest/pastor/Reverend prev. prefix give-help + NEG. nwáànyị isí-ḿkpe\# áhụ áká

+ cl. woman/girl widow DET. hand

"The pastor did not help that widow".

* (biii) Ụ́kọ̀chúkwú é nye ghí nwáànyị ísí-ḿkpe áhụ̀ áká

Priest/pastor/Reverend prev. prefix give + NEG. woman/girl widow DET. hand

"The pastor did not give that widow hand".

(ci) Ó mè rè ̀̀ yá

S/he/it do + -rv (PAST) I/me him/her/it

"He did it for me"

(cii) Ò mé ghi rí ḿ yá

$\mathrm{S} /$ he/it do + NEG. + cl I/me him/her/it

"He did not do it for me".

*(ciii) Ò mé ghí ḿ yá

S/he/it do + NEG. I/me him/her/it

"He did not do it to me". 
From the examples shown above, it is perceptible that it is not all the Ígbó verbs that accept only the simple negative suffix $g h i / g h i$ in the realization of their negative construction, rather, the service of the clitic $r i / r i$ is sometimes needed in some verbs for proper realization of the negative construction. Otherwise, the construction will be ungrammatical. See 11 (biii), and (ciii).At other times, the construction may be grammatical but the intended meaning will not be realized. See 11 (ciii).

\section{2 (d) Past tense in negative constructions the İmilìkè dialect}

Whereas in the standard dialect, the past tense negative construction is derived from its affirmative counterpart by the suffixation of the negative marker - ghi/-ghi "not" to the verb root (stem), in addition to the clitic ri/ri, sometimes, as discovered in this work, in İmilikè dialect the past tense negative formation is derived by the suffixation of the past tense negative markers -rágál-dágá denoting "did not", to the verb root (stem). In scrutinizing the first morpheme, -rága', intensely, the researchers discovered that the first syllable $-r a$ is just the $-r v$ past tense morpheme - $r$, while the second syllable - ga, is actually the negative marker. Scrutinizing the other marker which is -d'ga , the researchers being native speakers of the dialect intuitively understands that the first syllable - $d \partial$ ' actually stands for word "did" but also denotes emphasis. A native speaker can use -rágál-dágá as variants denoting "did not".

The formula for the derivation is: open vowel prefix (a-/e-) + verb root $($ stem $)+r a+g a$, or open vowel prefix $(a-/ e-)+$ verb root $($ stem $)+d \partial+$ ga. Consider these constructions: 
12. (ai) Onye ńkózó tạ́ rọ̀ nwá ha ọnự

Person teaching scold +-rv (PAST) baby/child DET. mouth "The teacher scolded this child".

(aii) Onye ńkózó á tạ̀ rọ̀ gạ nwá ha ộnụ́ Person teaching prev. prefix scold + -rv (PAST) + NEG. baby/child DET. mouth

"The teacher did not scold this child".

(bi) Nwákàégo chụ̀ rạ̀ ệkwà n' ụ̣tụ̂tụ

Nwákàégo wash + -rv (PAST) cloth PREP. morning "Nwákàégo washed clothes in the morning".

(bii) Nwákàégo á chụ rạ́ gạ ẹ́kwà n' ụ̀tụtụ̀ Nwákàégo prev. prefix wash +-rv (PAST) + NEG. cloth PREP. morning "Nwákàégo did not wash clothes in the morning".

(biii)

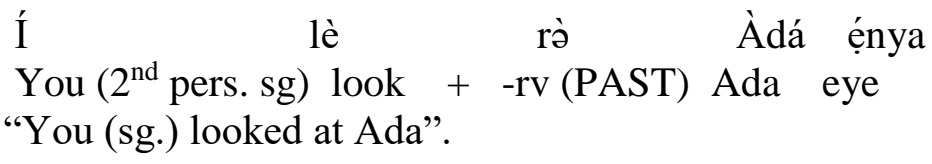

(ci) Í le dó gá Àdá ệnya You ( $2^{\text {nd }}$ pers.sg. pro.) look + -rv (PAST) EMPH (did) NEG. Ada eye "You (sg.) did not look at Ada". (emphatic)

(cii) Únú jụ̀ rò ọ̀tọ́tọ́ èsè n’ ụ́zọ̀ You ( ${ }^{\text {nd }}$ ppl. pro.) ask + -rv (PST) many/plenty/a lot question PREP. way/road "You (pl.) asked a lot of questions on the way". 


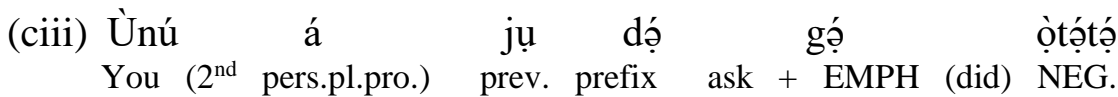
many/plenty/a lot

ẹ̀sẹ $\quad$ n’ ụ́zọ̀

question PREP. Way road

(emphatic)

"You (pl.) did not ask a lot of question on the way".

Using Bull (1963) as contained in Omamor (1982) as a theoretical framework to analyze the data, we want to state that the situations or events being described in the constructions in ' 11 ' and ' 12 ' in both standard Igbo and İmilikè dialect are definitely anterior to the time of utterance, since the beginning, the middle and the end took place before the moment of speech. However, the sentences describe situations, events or states of affairs which as at the moment of speech, have not taken place, but may nevertheless take place later.

The essence of citing the examples in 11 (ciii) and (diii) is to confirm that in some negative constructions, it is not only the negative marker $g h i / g h i$ that can be employed in the derivation of negative construction. This is to signify that some verbs require the presence of the clitic ri/ri to be merged with the negative suffix ghi/ghi so as to correctly realize the intended meaning

\section{2 (e) Observations and summary on the past tense in the affirmative and negative constructions in the standard Ígbò and İmilìkè dialect}

When the NP(s) subject is a noun, a noun phrase, or a plural pronoun in a negative construction in both dialects, the verb root (stem) must possess a high tone preverbal prefix á-/é-, whereas, the tone on the vowel of the verb root (stem) is a downstep. However, 
there are tonal differences on the negative suffix in both dialects. This is because in the standard Ígbò the tone on the negative suffix is a high tone, while in the İmilikè dialect, the tone on the negative suffix depends on the tone class of the verb concerned. For instance, the tone on the negative suffix may be high or low depending on the tone class of the verb. Taking a cue from the constructions, it would be observed that while the tone on the negative marker ga "not" in12 (aii) is a low tone, that on12 (bii) and (cii) are on high tones.

On the other hand, when the $\mathrm{NP}(\mathrm{s})$ is a singular pronoun, the pronoun has a high tone, while the vowel of the verb root (stem) is a downstep in in the standard Ígbò, while the preverbal prefix in both dialects is deleted. In the standard Ígbò, the tone on the negative suffix possesses a high tone, whereas in the İmilikè dialect, the tone on the vowel of the verb root (stem) and that of the negative dialect depends on the tone class of the verb. For instance, an observation of the sentence in 12 (cii) reveals that the tone on the vowel of the verb root (stem) is a downstep, while that on the negative marker ga "not" is a high tone. In 12 (cii), the tones in the vowel of the verb root (stem) and that of the negative morpheme gá are all low tones.

In the standard Ígbò, the derivational pattern reveals that in the affirmative construction, the derivation is carried out using this formula: verb root (stem) + -rv past morpheme, while in the negative construction, it was observed that when the NP(s) subject is a noun, a noun phrase, or a plural pronoun, the formula for the derivation is: open vowel prefix $(\mathrm{a}-/-\mathrm{e})+$ verb root (stem) + (negative suffix) ghí/ghí. However, when the $\mathrm{NP}(\mathrm{s})$ subject is a singular pronoun, the open vowel prefix (a-/-e) is not realized. In 
that case, the formula for the derivation of the negative construction becomes: the verb root (stem) + (negative suffix) ghighi. In the İmilikè dialect, when the $\mathrm{NP}(\mathrm{s})$ subject is a noun, a noun phrase, or a plural pronoun, the formula for the derivation of the negative construction is: open vowel prefix $(a-/-e)+$ verb root (stem) $+r v$ past morpheme (ro) + (negative suffix) ga, or open vowel prefix ( $a$ /-e) + verb root (stem) + emphasizer $(d \partial)+(($ negative suffixes $)) g \partial$, Nevertheless, when the NP(s) subject is a singular pronoun, the open vowel prefix (a-/-e) is not realized just as in the standard Ígbò. When this applies, then, the formula for the derivation of the negative construction becomes: verb root (stem) $+r v$ past morpheme (rə) + (negative suffix) gə, or verb root (stem) + emphasizer $(d \partial)+(($ negative suffixes $)) g \partial$,

Table 2: The various Tense markers in the standard Ígbò and the İmìlikè dialect

\begin{tabular}{|c|c|c|}
\hline The Tenses & $\begin{array}{l}\text { The Tense } \\
\text { Markers }\end{array}$ & \\
\hline \multirow[t]{4}{*}{$\begin{array}{l}\text { The Present } \\
\text { Tense }\end{array}$} & $\begin{array}{l}\text { Affirmative } \\
\text { Construction: }\end{array}$ & \\
\hline & $\begin{array}{l}\text { Standard } \\
\text { Ígbò }\end{array}$ & $\begin{array}{l}\text { Simple (CV) structured } \\
\text { verbs like "bu", "kwọ̀" and } \\
\text { other simple verbs like àbịá, } \\
\text { ègó }\end{array}$ \\
\hline & $\begin{array}{l}\text { İmilikè } \\
\text { Dialect }\end{array}$ & $\begin{array}{l}\text { Simple (CV) structured } \\
\text { verbs like "vo", "kwọ̀" and } \\
\text { other simple verbs like àbịá, } \\
\text { ègó }\end{array}$ \\
\hline & Negative & \\
\hline
\end{tabular}




\begin{tabular}{|c|c|c|}
\hline & Construction & \\
\hline & $\begin{array}{l}\text { Standard } \\
\text { Ígbò }\end{array}$ & ghị/ghi \\
\hline & $\begin{array}{l}\text { İmilikè } \\
\text { Dialect }\end{array}$ & $-g \partial ́$ \\
\hline \multirow[t]{6}{*}{$\begin{array}{l}\text { II. The Past } \\
\text { Tense }\end{array}$} & $\begin{array}{l}\text { Affirmative } \\
\text { Construction }\end{array}$ & \\
\hline & $\begin{array}{l}\text { Standard } \\
\text { Ígbò }\end{array}$ & $\begin{array}{l}\text { The"-rv"past tense } \\
\text { morpheme }\end{array}$ \\
\hline & $\begin{array}{l}\text { İmilìkè } \\
\text { Dialect }\end{array}$ & $\begin{array}{l}\text { The -rv past morpheme rọ/- } \\
\text { rə }\end{array}$ \\
\hline & $\begin{array}{l}\text { Negative } \\
\text { Construction }\end{array}$ & \\
\hline & $\begin{array}{l}\text { Standard } \\
\text { Ígbò }\end{array}$ & -ghị/-ghi(ri) \\
\hline & $\begin{array}{l}\text { İmilikè } \\
\text { Dialect }\end{array}$ & -gə́, də́gว́ \\
\hline & & \\
\hline
\end{tabular}

\section{Summary and conclusion}

The ample evidence of affixation which is involved in the derivation of the past, the future tense, and even sometimes, in the derivation of the present tense, all accounts for the morphological distinctions that do exist in the internal structure of Ígbó verbs when they are being employed in either, the present, the past or the future 
tenses in language. Some of the observations made reveal that there is indeed, morphological opposition between the present and past tense in the İmilikè dialect. It was observed that a sub-set of Igbó verbs with one syllable (CV) structure which are consistently on low tones are employed in the derivation of the present tense. However, sometimes, compound verbs can as well occur in this type of tense.

In the standard Ígbò and the İmìlikè dialect, the past tense formation is derived by the suffixation of the - $r v$ past morpheme to the existing verb root (stem). Nevertheless, it was observed that while the vowel of the $-r v$ past marker rhymes with the vowel in the verb root (stem) in the standard Ígbò. This is not the case in the İmilikè dialect since the $-r v$ past morpheme is always the schwa which is realised as either the central vowel (ə) or (o), due to the heavy dependence on the vowel harmony which is very prevalent in the dialect. Whereas in the standard Ígbò, the past tense negative construction is derived from its affirmative counterpart by the suffixation of the negative marker -ghi/-ghi "not" to the verb root (stem), in addition to the clitic ri/ri, sometimes, as discovered in this work; in the İmilikè dialect the past tense negative formation is derived by the suffixation of the past tense negative markers rágá/-dágá denoting "did not", to the existing verb root (stem). However, proper scrutiny revealed that while the first morpheme, $r \partial$ in the morpheme -raga, is actually, the - $r v$ past tense marker $r \partial$, the second syllable -go, is actually the negative marker. On the other hand, the morpheme - dágá is employed by a speaker when he/she wants to be emphatic. The emphasis is realised by the choice of the application of the morpheme -dá instead of -ro' in the negative construction. 
It was specified that the future tense or future time in Ígbò is expressed by employing modal verbs or auxiliaries which has to be connected to the main verb through the use of a hyphen. The main verb is also called the participle due to its possession of a prefix that makes it to be in its participle form. Nevertheless, in the İmilikè dialect, the future marker $j i$ which means "will/would" is not at all connected to the prefix of the main verb during the process of the derivation of an affirmative sentence.

In order to derive a negative future tense construction from its affirmative counterpart in the standard Ígbò, the negative marker ghi meaning "not" is suffixed to the future tense marker, which is the auxiliary verb $g \grave{a}-$. This is followed by the main verb which must be in its participle form by possessing of a preverbal prefix $a$ le-. In the derivation of a negative construction from its affirmative counterpart, in the İmilikè dialect, the main negative marker that is used is go. However, it was observed that in the dialect, the negative suffix gá cannot stand alone without the morpheme -kó/-kó, which from our analysis, actually stands as, or really means "will/shall" or "would/should". In other words, it replaces the modal verb $j a-/ j i$ "will/would" which is used in the affirmative construction.

Juliana Chizọbam Eze is of Federal College of Education, Okene, Kogi State. marvellousloveofgod@gmail.com

Ifeoma M. Nweze is of the Department of Linguistics and Nigeria Languages Alex Ekwueme Federal University, Ndufo Alieke Ebonyi State. ifeomanweze62@yahoo.com 


\section{References}

Aleh, E. (2013). Tense and aspect in Urhobo. Issues in contemporary African linguistics: A

festschrift for Ọladele Awobuluyi. Ozo-Mekiru Ǹdịmèlé, L. C. Yuka, and J. F. Ilọiri

(Eds.) Port Harcourt: Linguistic Association of Nigeria in Collaboration with M \& J Grand

Orbit Communications Ltd..151 - 162.

Àchèbé, I., Éme, C., Émenańjọ́, E. N., Íkékéọ́nwụ́, C. and Wanjiku N. (2011). A composite

synchronic alphabet of Igbo dialects (CSAID): Guidelines for data. Transcription. New

York: Ígbó Archival Dictionary, Inc.

Dosunmu, O. O. (2010). Tense and aspect in Yagba dialect of Yorùbá. MA dissertation. University of

Ibadan, Nigeria.

Ègwím, J. C. (2008). Ntọálà útọ́ásùsư İgbò màkà ńdị SSCE, College of Education na ńdi Yùnívásítị.

Ibadan: Safmos Publishers.

Émenańjọ́, E. N. (1987). Elements of modern Ígbó grammar. Ibadan: University Press Limited.

Émenańjọ́, E. N. (2000). Ńchịkọtá àsùsù İgbó İzùgbé. Lagos: Longman Nigeria PLC.

Éyì̀ì, J. (2006). A grammar of English: The student's companion.

Nimo: Rex Ltd.

Íbè, B. (2007). Teaching of tenses current concepts and methods that impede the learning of verb usage.

In. B. N. Ànàsịúdù, G. I. Nwáòzùzù and C. N. Òkèbàlámá (Eds.) Language and literature in a 
developing country: Essays in honour of B. O. A. Oluikpe. (pp. 260 - 273). Onitsha: Africana-

First Publishers Limited.

Ígwe, G. E. and Green, M. M. (1979). A short Igbo grammar in the official orthography Ibadan:

University Press Limited.

Íkégwụọ́nụ, C. N. (2011). Tense as an element INFL phrase in Ígbò. Journal of Ígbó Language

\& Linguistics. 3. $112-121$.

Nwáòzùzù, G. I. (2008). Dialects of Igbo language. Nsukka: University of Nigeria Press Ltd.

Nwáǹzé, R. E. (1991). Mụá İgbò: Ígbó grammar for language students. Lagos: In-way Publishers.

Nwéyà, G. O. (2010). Phonotactics in Ígbò: The İmìlikè dialect example. MA Dissertation,

Ńnàmíị Ázịkíwé University, Àwká.

Nwézè, I. M. (2009). Inflections in İmìlikè dialect of Ígbó language. Journal of Ígbó Language

\& Linguistics, 1. 117-137.

Ộọ̣màtá, C. E. (2005). Ńdézù útọásùssư Ígbò ǹkè ndị jụniọo sékọnndịrị, Enugu: Format Publishers.

Ọfọ́màtá, C. E. (2010) Ńdézù Ưtọáásùsư Ígbò ǹkè ńdị sịnịọ sékọndịnị̂, Enugu: Format Publishers.

Ògbu $\perp$, S. E. (2011). The history of İmilikè. Nsukka: Chúkà Educational Publishers

Ộhá, A. B. (2004). Affixing strategies in Mgbidi inflection. Unizik Journal of Arts and Humanities. 3, 242-261. 
Táíwò, O. and Angisto, M. T. (2013). Tense and aspect in Tiv. Linguistics and the globalization

of African languages for sustainable development: A festschrift in honour of Kola Owolabi Wale

Adegbite, Ayo Ogunsiji, and Oye Taiwo. Eds. Ibadan: Universal Akada Books Limited, 331 - 350

Ụ̂wàlákà, M. A. (1998). The Ígbó verb: A semantico-syntactic analysis. Wien: Beiträge zur

Afrikanistik. 